Yuzuncu Yil University
Journal of Agricultural Sciences

Research Article (Araştırma Makalesi)

\title{
Pollen and Physicochemical Analysis of Honey Samples from Akçakoca and Yığılca District (Western Black Sea)
}

\author{
Bahar GÜRDAL*1, Sefa SÖNMEZ ${ }^{2}$
}

\author{
${ }^{1}$ İstanbul University, Faculty of Pharmacy, Department of Pharmaceutical Botany, Istanbul, Turkey \\ ${ }^{2}$ Altınbaş University, Faculty of Pharmacy, Department of Pharmaceutical Botany, Istanbul, Turkey \\ ${ }^{1}$ https://orcid.org/0000-0003-4009-100X ${ }^{2}$ https://orcid.org/0000-0002-1789-865X \\ *Corresponding author e-mail: bahar.gurdal@istanbul.edu.tr
}

\section{Article Info}

Recieved: 15.04 .2021

Accepted: 04.07.2021

Online Published: 15.09 .2021

DOI:10.29133/yyutbd.916781

\section{Keywords}

Apis mellifera,

Düzce,

Melissopalynology,

Yı̆̆llca local honey bee

\begin{abstract}
Turkey, with its rich flora and high endemism proportion in a temperate zone, is highly favorable for beekeeping. In the studied area, two honeybees are present: Apis mellifera anatoliaca and the Yığılca local honeybee, which has been determined as local ecotype of anatoliaca in the Black Sea region. The main objective of this study was to determine the botanical sources of honey samples, which are produced by these two honeybees, from Akçakoca and Ylğılca district. Chestnut and mad honey samples were obtained from local beekeepers. Pollen types in the honey samples were identified and determined the frequency classes. Castanea sativa was identified as the predominant pollen among the honey samples of Anatolian honeybee; these samples were classified as monofloral honey. Besides, Rhododendron ponticum and Lysimachia verticillaris pollens were found to be the important minor pollens in the mad honey samples of Anatolian honeybee. Mad honey samples from the Yığılca local honeybee were a multifloral honey and included Rhododendron ponticum and five other pollens as important minor pollen. In addition, physicochemical analyses were also performed. The honey samples gathered from the Yığılca district were deemed acceptable. On the other hand, the honey samples from the Akçakoca district were found acceptable except for moisture content. Also, 104 plant specimens were collected around beehives and 54 taxa were reported as melliferous plants. The Sorensen similarity coefficient, calculating among the melliferous plants of two localities (Akçakoca and Yığılca), was $51.85 \%$. Diversity of melliferous plants was also higher in Yığılca than in Akçakoca.
\end{abstract}

\section{Akçakoca ve Yığılca İlçelerinden (Batı Karadeniz) Bal Örneklerinin Polen ve Fizikokimyasal Analizi}

\section{Makale Bilgileri}

Geliş: 15.04 .2021

Kabul: 04.07.2021

Online Yayınlanma: 15.09.2021

DOI: $10.29133 /$ yyutbd.916781

\section{Anahtar Kelimeler}

Apis mellifera

Düzce,

Melissopalinoloji,

Yığglca lokal balarısı
Öz: Türkiye, 1lıman bölgede zengin bitki örtüsü ve yüksek endemizm oranı ile arıcılık için oldukça elverişlidir. Çalışma alanında Apis mellifera anatoliaca ve Karadeniz bölgesinde anatoliaca'nın ekotipi olarak belirlenen Yığılca lokal bal arısı olmak üzere iki bal arısı bulunmaktadır. Bu çalışmanın temel amacı, Akçakoca ve Yığılca'dan alınan bu iki bal arısına ait balların botanik kaynaklarını belirlemektir. Kestane ve deli bal örnekleri yerel arıcılardan temin edilmiştir. Bal örneklerindeki polen türleri belirlenmiş ve frekans sınıfları belirlenmiștir. Castanea sativa, Anadolu bal arısı kestane ve deli bal örnekleri arasında baskın polen olarak belirlenmiştir; bu örnekler monofloral bal olarak sınıflandırılmıştır. Ayrıca Anadolu bal arısı deli bal örneklerinde Rhododendron ponticum ve Lysimachia verticillaris polenleri önemli minör polenler olarak tespit edilmiştir. Yığılca lokal 
bal arısından elde edilen deli bal örnekleri, multifloral baldır ve önemli minör polen olarak Rhododendron ponticum ve diğer beş türün polenini içermektedir. Ayrıca fizikokimyasal analizleri de yapılmıştır. Yı̆̆ılca ilçesinden toplanan bal örneklerinde değerler kabul edilen sınırlar içindedir. Öte yandan Akçakoca ilçesinden alınan bal numunelerinde, nem içeriği dışındaki değerler kabul edilebilir bulunmuştur. Ayrıca, arı kovanlarının etrafında 104 bitki örneği toplanmış ve 54 takson ballı bitki olarak belirlenmiştir. İki ilçenin (Akçakoca ve Yığılca) ballı bitkileri arasında hesaplanan Sorensen benzerlik katsayısı \% 51.85 olarak bulunmuştur. Yığılca ilçesinde ballı bitki çeşitliliği de Akçakoca ilçesine göre daha fazladir.

\section{Introduction}

Beekeeping is a widespread profession in Turkey, where honey is an important food product for the local people of the country in question. According to FAO (2016) data on the number of beehives globally, Turkey ranks third in the world, with the third highest number of beehives across all countries surveyed. As of 2019, the number of beehives in Turkey has reached 8.1 million, and the nation's honey production measures about 110 thousand tons (TUIK, 2019). The botanical source of pollen harvested by honey bees possesses an important role in the quality of honey produced. Hence, pollen analysis of honey possesses prominent importance due to its ability to reveal the plant species foraged by honey bees for the honey source. In the literature, recently there exist numerous studies investigating the melissopalynology of Turkish honeys (Altay et al., 2018; Gencay Celemli et al., 2018; Gül and Pehlivan, 2018; Ozkok et al., 2018; Özenirler et al., 2018; Özler, 2018; Bozbeyoglu et al., 2019; Cenet, 2019; Ecem Bayram et al., 2019; Gürbüz et al., 2019a; b; Kızılpınar Temizer et al., 2019; Çakır et al., 2020; Gencay Celemli, 2020).

Turkey is home to varying climatic and ecological conditions. The nation is also a natural transition point between Europe, Asia and Africa, creating a gene pool that contains many bee race and ecotypes (Adam, 1983; Kılıç and Bilgen, 2006; Kambur Acar and Kekeçoğlu, 2020). Apis mellifera, which was originally discovered in Asia, Europe, and Africa, but has since spread globally due to human intervention, possesses five subspecies in Turkey (Ruttner, 1988). These subspecies are Apis mellifera subsp. carnica in the European part of Turkey (Thrace), A. mellifera subsp. caucasica in the northeast region of Turkey, A. mellifera subsp. meda in the east of Turkey, A. mellifera subsp. syriaca in the southeast of Turkey, and A. mellifera subsp. anatoliaca in the rest of Anatolia (Kandemir et al., 2000). In recent studies, the Yığılca local honey bee has been found in the Düzce province (Black Sea Region, Turkey). The Yığglca district (Düzce province) is a region with no entrances and exits for bees due to its natural geology and structure (Gösterit et al., 2012). The Yı̆̆1lca local honey bee, which is considered to be an ecotype native to the specific region examined, has been studied by Kekecoglu (2010) and it is reported that, according to both COI gene SspI restriction polymorphism and 18 vessel angle coordinates, this bee is endemic to the Yığılca district of the Düzce province. In an additional study conducted by Kekecoglu and Soysal (2010), it was discovered that the morphometric characteristics of honey bees in the Yığılca district (Düzce) demonstrated a local ecotype of anatoliaca. In this study, Kekecoglu and Soysal (2010) also highlighted that no imported honey bees had inhabited or been brought to the Yığllca district for over 30 years, and that there exist no modern beekeeping manipulations in the population studied. Apis mellifera subsp. anatoliaca (known as the Anatolian honey bee) is also a common subspecies in Düzce, but the Yiğılca district is an isolated region from other districts in Düzce.

In this study, the main objective is to determine the botanical sources of honeys of the Yığılca local honey bee and Apis mellifera subsp. anatoliaca using melissopalynological analysis in Düzce. The study also aimed to evaluated the physicochemical properties of honey samples and to determine melliferous plants around beehives. Following the aims of this study, chestnut honey and mad honey, two important honeys in the Düzce province, were selected and obtained from local beekeepers. 


\section{Material and Methods}

\subsection{Study area}

The research areas of this study were the Akçakoca and Yığılca districts of the Düzce province in Turkey (Figure 1). The Düzce province is located in the Western Black Sea region of the country. The land mass area of Düzce with its eight districts (Merkez, Akçakoca, Cumayeri, Çilimli, Gölyaka, Gümüşova, Kaynaşlı and Yı ̆ğlca) is $2593 \mathrm{~km}^{2} .50 \%$ of this area is composed of forestland (Düzce Municipality, 2019). Akçakoca is the sole district within the province of Düzce containing a coastline of $30 \mathrm{~km}$ and possessing a sea border. The surface area of the district in question is $463 \mathrm{~km}^{2} .40 \%$ of the district is forested and is home to 43 villages (Akcakoca Municipality, 2019). The district of Yığılca is bordered by the Zonguldak province in the north, Bolu province in the east and south, Akçakoca district in the northwest, and Kaynaşlı district in the southwest (Yı ğllca Municipality, 2019). Its surface area is $640 \mathrm{~km}^{2}$, and $65 \%$ of the district is covered with forests (Yığllca Department of Forestry, 2019). The Y1ğılca district is home to 39 villages.

According to recent data of the Provincial Directorate of Agriculture and Bee Breeders in the Düzce province of Turkey, there were 594 beekeepers and 53823 hive bees registered in 2017 in the region. Beekeepers possessing 30 or more hives are included in this data. The number of beekeepers is considered to be nearly 1000 regardless of the number of hives. The annual production of registered beekeepers amounts to $386268 \mathrm{~kg}$ honey, $8980 \mathrm{~kg}$ beeswax, and $453 \mathrm{~kg}$ pollen. The production of royal jelly is produced by only a few beekeepers in the Düzce province, and their annual output is $4.936 \mathrm{~kg}$.

According to the information sourced from local beekeepers, several types of honey are produced in the Düzce province. The types constitute chestnut honey, mad honey, plateau blossom honey, and blossom honey. Chestnut honey is produced by bees when the chestnut trees (Castanea sativa) bloom in June. Mad honey is produced during the intense flowering of Rhododendron spp. in the month of May.

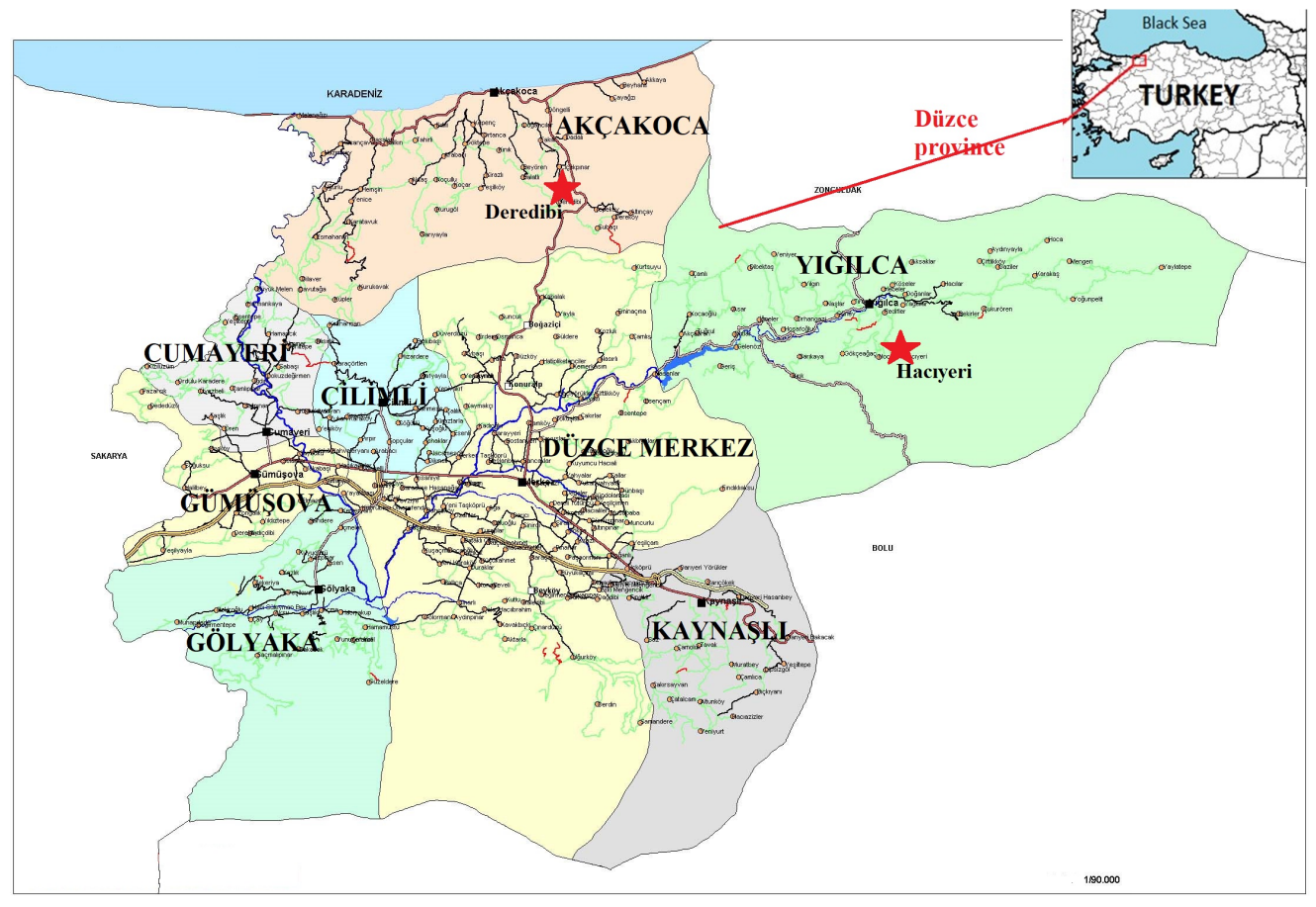

Figure 1. Study area on the map. * shows the sampling site.

\subsection{Melliferous plants}

The fieldwork portion of this study was carried out between May 2017 and June 2017. A total of 104 melliferous plants were collected near the hives during six field trips within the region. The plants 
were collected from a $0.8 \mathrm{~km}$ radius around the beehives, to be compared with the pollen in the honey samples gathered. Interviews were also conducted with beekeepers during the course of the fieldwork in order to understand the melliferous flowers present, bee types, and other necessary details relevant to the study. During the fieldwork portion of this study, the plants that flowered during the honey period in question and with high patronage by the honey bees studied were in particular collected.

Melliferous plants in proximity to the beehives in this study were identified. The collected plant specimens were identified using "Flora of Turkey and the East Aegean Islands" (Davis, 1988; Güner et al., 2000) and compared to the specimens contained within the ISTE (the Herbarium of the Faculty of Pharmacy of Istanbul University). The plant materials collected in our study were kept within the ISTEHoney Plants Herbarium as herbarium samples.

The pollen slides of the collected plants were prepared following the Wodehouse (1935) method to obtain reference pollen images from within the identified plants. Pollen photos were captured using an Olympus BX53 light microscope.

\subsection{Honey samples and melissopalynological study}

Honey samples were obtained directly from local beekeepers. Honeys were labeled by the beekeepers as chestnut and mad honey. Chestnut (honey 1) and mad honey (honey 2) of the Yiğılca local honey bee were collected from Haciyeri village, Yığılca district. Chestnut (honey 3) and mad honey (honey 4) of Apis mellifera subsp. anatoliaca were collected from Deredibi village, Akçakoca district. The floral sources of the honeys were determined following the mellisopalynological method. For examination procedures of the pollen and the identification of honeys, 10 samples were prepared from each honey (chestnut honey and mad honey of both the Anatolian honey bee and the Yiğilca local honey bee) according to the methods of Louveaux et al., (1978) and Sorkun (2008).

Pollen counting was conducted using an Olympus BX53 light microscope. 10 slides were prepared for each honey sample. The pollen was then identified based on the number of apertures, sculptures, structures, and sizes of the pollen. Slides were prepared as homogeneously dispersed and at least 500 pollen grains per sample were counted. The average value of the results for each honey sample after counting was calculated as percentages. Based upon these results, the honey samples were classified into four different frequency classes as predominant (more than $45 \%$ ), secondary $(16 \%-45 \%$ ), important minor $(3 \%-15 \%)$ and minor (less than $3 \%$ ) pollen according to their pollen percentages (Louveaux et al., 1978).

For pollen diagnosis, the prepared pollen slides from the studied honeys samples were compared with the pollen slides of melliferous plants. Books, pollen library, and related studies to our survey (Silici and Gökceoglu, 2007; Sorkun, 2008; Hesse et al., 2009; Halbritter et al., 2010; Sorkun et al., 2014) were also used in pollen diagnosis.

\subsection{Physicochemical analysis}

Diastase, sugar (Fructose + Glucose, Fructose / Glucose, Sucrose, Maltose), C4 sugar percentages, difference $\delta^{13} \mathrm{C}$ protein $-\delta^{13} \mathrm{C}$ honey, $\mathrm{HMF}$ (hydroxymethyl furfural), moisture, conductivity, free acidity, and proline tests were performed by the Düzce University Scientific and Technological Research Application and Research Center for each honey sample studied (Kekecoglu and Goc-Rasgele, 2013; Derebaş1 et al., 2014; Kambur et al., 2015). According to the analyses of the Turkish food codex communiqué on honey (Ministry of Food, Agriculture and Livestock, 2012), tests were conducted on each sample.

\subsection{Statistical analysis}

Sorensen's similarity coefficient (Moraes et al., 2019) was calculated to compare the pollen/botanical sources between the Yiğglca local honey bee and the Anatolian honey bee. Formula is ISS $=2 a /(a+b+c) \times 100$, where a refers to number of pollen/species common to $x$ and $y, b$ to number of pollen/species restricted to $\mathrm{x}$, and $\mathrm{c}$ to number of pollen/species restricted to $\mathrm{y}$. This coefficient indicates the pollen/species common to both honey bees. 


\section{Results}

\subsection{Melliferous plants}

Field studies that we conducted in proximity to the beehives in question lead to the collection of 104 plant specimens. 54 taxa belonging to 23 families were reported as melliferous plants. Flowers visited by honey bees in addition to the observation of beekeepers were also recorded. The pollen type of each species was determined and then used as a reference collection. This information is summarized in Table 1. Pollen photos of some melliferous plants are shown in Figure 2. The Sorensen similarity coefficient (ISS), calculating among the melliferous plants of two localities (around the beehives of the Yığılca and the Anatolian honey bees), was 51.85\%.
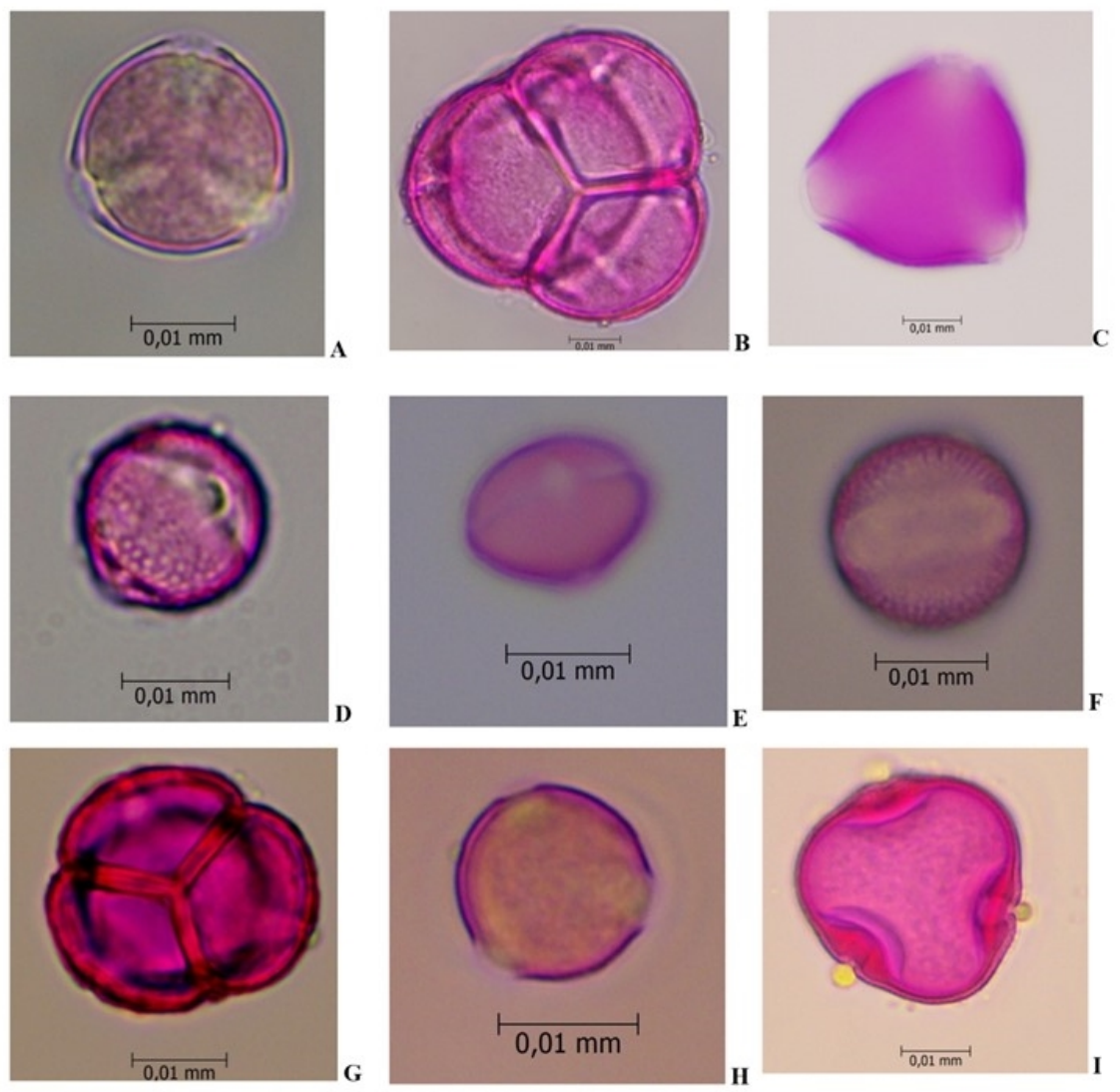

Figure 2. Pollen photos of some melliferous plants, which are determined in the studied area.

A- Polar view of Hypericum calycinum pollen, B- Pollen of Rhododendron ponticum, C- Polar view of Prunus laurocerasus pollen, D- Equatorial view of Lysimachia verticillaris pollen, E- Pollen of Castanea sativa F- Equatorial view of Barbarea vulgaris pollen, G- Pollen of Erica arborea, H- Polar view of Echium vulgare pollen, I- Polar view of Tilia tomentosa pollen.

\subsection{Melissopalynological analysis}

According to the information we received from the beekeepers interviewed, several honey types are produced in Düzce. The types produced include chestnut honey, mad honey, plateau blossom honey, and blossom honey. In the present study, melissopalynological analysis of chestnut honey and mad honey was carried out on honey belonging to different honey bees, the Yığılca local honey bee and the Anatolian honey bee, in Düzce. We obtained honey samples that were labeled as chestnut honey from the local beekeepers in the region. Honey samples are produced by the Yiğllca local honey bee and the Anatolian honey bee.

Chestnut honey samples from the Yiğglca local honey bee and the Anatolian honey bee were classified as monofloral, with a rate of $94.5 \%$ and $96.5 \%$ chestnut (Castanea sativa) pollen in the 
samples, respectively. There was no group of secondary and important minor pollen grains presence in the samples investigated. Apiaceae, Caryophyllaceae, Hypericum androsaemum, and Trifolium repens are a group of minor pollen in Yiğılca chestnut honey samples. On the other hand, minor pollen group was represented by Securegia varia, Tilia tomentosa, and Trifolium repens in Anatolian chestnut honey samples (Table 2).

Table 1. List of melliferous plants and pollen type in the studied area

\begin{tabular}{|c|c|c|}
\hline Botanical name & Family & Specimen number (ISTE) \\
\hline Agrimonia eupatoria $\mathrm{L}$. & Rosaceae & 115626 \\
\hline Anthemis tinctoria var. pallida DC. & Asteraceae & 115628 \\
\hline Asperula involucrata Wahlenb. & Rubiaceae & 115575 \\
\hline Barbarea vulgaris R.Br. & Brassicaceae & 115559 \\
\hline Calystegia silvatica (Kit.) Griseb. & Convolvulaceae & 115586,115607 \\
\hline Campanula lyrata Lam. & Campanulaceae & 115618 \\
\hline Carduus nutans $\mathbf{L}$. & Asteraceae & 115621 \\
\hline Castanea sativa Mill. & Fagaceae & $115583,115601,115587,115517$ \\
\hline Circaea lutetiana $\mathrm{L}$. & Onagraceae & 115603 \\
\hline Clinopodium vulgare subsp. arundanum (Boiss.) Nyman & Lamiaceae & 115627 \\
\hline Cytisus hirsutus L. & Leguminosae & 115538 \\
\hline Dorycnium graecum (L.) Ser. & Leguminosae & $115578,115550,115551,115581$ \\
\hline Echium vulgare $\mathrm{L}$. & Boraginaceae & 115629 \\
\hline Erica arborea $\mathbf{L}$. & Ericaceae & 115562,115572 \\
\hline Fagus orientalis Lipsky & Fagaceae & 115556,115557 \\
\hline Fragaria vesca $\mathrm{L}$. & Rosaceae & 115535,115549 \\
\hline Galega officinalis L. & Leguminosae & 115591,115624 \\
\hline Geranium asphodeloides Burm.f. & Geraniaceae & 115568 \\
\hline Geranium purpureum Vill. & Geraniaceae & 115631 \\
\hline Hypericum androsaemum $\mathrm{L}$. & Hypericaceae & $115554,115555,115588$ \\
\hline Hypericum calycinum $\mathrm{L}$. & Hypericaceae & $115597,115606,115620$ \\
\hline Hypericum montbretii Spach & Hypericaceae & 115625 \\
\hline Hypericum perforatum $\mathrm{L}$. & Hypericaceae & 115604 \\
\hline Hypochoeris radicata $\mathrm{L}$ & Asteraceae & 115613 \\
\hline Lathyrus laxiflorus (Desf.) Kuntze & Leguminosae & 115569 \\
\hline Lotus tenuis Waldst. \& Kit & Leguminosae & 115612 \\
\hline Lysimachia punctata $\mathrm{L}$. & Primulaceae & 115582,115585 \\
\hline Lysimachia verticillaris Spreng. & Primulaceae & 115609,115632 \\
\hline Medicago lupulina $\mathbf{L}$. & Leguminosae & 115635 \\
\hline Mespilus germanica $\mathbf{L}$. & Rosaceae & 115573,115574 \\
\hline Myosoton aquaticum (L.) Moench & Caryophyllaceae & 115599 \\
\hline Poaceae sp. & Poaceae & - \\
\hline Potentilla anglica Laichard. & Rosaceae & 115595,115623 \\
\hline Prunella vulgaris $\mathbf{L}$. & Lamiaceae & 115602,115634 \\
\hline Prunus laurocerasus L. & Rosaceae & $115563,115579,115580$ \\
\hline Ranunculus repens $\mathrm{L}$. & Ranunculaceae & $115558,115541,115547,115548$ \\
\hline Rhododendron ponticum $\mathrm{L}$. & Ericaceae & $115536,115540,115564,115565,115566,115567$ \\
\hline Rubus hirtus Waldst. \& Kit. & Rosaceae & 115595,115608 \\
\hline Rubus ulmifolius Schott. & Rosaceae & 115614 \\
\hline Salvia forsskaolei $\mathrm{L}$. & Lamiaceae & 115616 \\
\hline Salvia verticillata $\mathrm{L}$. & Lamiaceae & 115611 \\
\hline Sambucus ebulus L. & Adoxaceae & 115615 \\
\hline Sambucus nigra $\mathrm{L}$. & Adoxaceae & 115584 \\
\hline Saponaria glutinosa M. Bieb. & Caryophyllaceae & 115619 \\
\hline Securegia varia (L.) Lassen & Leguminosae & 115622,115628 \\
\hline Sonchus asper subsp. glaucescens (Jord.) Ball ex Ball & Asteraceae & 115636 \\
\hline Tanacetum parthenium (L.) Sch. Bip. & Asteraceae & 115589,115633 \\
\hline Tilia tomentosa Moench & Malvaceae & $115592,115593,115610$ \\
\hline Trachystemon orientalis D.Don & Boraginaceae & 115560,115561 \\
\hline Trifolium repens var. repens $\mathrm{L}$. & Leguminosae & $115577,115552,115598$ \\
\hline Vaccinium arctostaphylos $\mathbf{L}$. & Ericaceae & $115539,115571,115576,115544$ \\
\hline Verbascum sp. & Scrophulariaceae & - \\
\hline Verbena officinalis $\mathbf{L}$. & Verbenaceae & 115605 \\
\hline Veronica sp. & Plantaginaceae & 115537,115546 \\
\hline
\end{tabular}


Table 2. Melissopalynological analysis of chestnut honey samples of Yığılca and Anatolian honey bee

\begin{tabular}{lll}
\hline \multicolumn{1}{c}{ Botanical origin } & Honey 1 \% (frequency)* & Honey $\mathbf{3} \%$ (frequency)* $^{*}$ \\
\hline Castanea sativa & $94.5(\mathrm{PP})$ & $96.5(\mathrm{PP})$ \\
Apiaceae & $1.5(\mathrm{MP})$ & - \\
Caryophyllaceae & $1.5(\mathrm{MP})$ & - \\
Hypericum androsaemum & $1.5(\mathrm{MP})$ & - \\
Securegia varia & - & $1.5(\mathrm{MP})$ \\
Tilia tomentosa & - & $0.5(\mathrm{MP})$ \\
Trifolium repens & $1.5(\mathrm{MP})$ & $0.5(\mathrm{MP})$ \\
Not identified & 1.5 & 1 \\
\hline
\end{tabular}

* PP: predominant pollen ( $>45 \%)$. SP: secondary pollen (16-45\%). IMP: important minor pollen (3-15\%). MP: minor pollen $(<3 \%)$.

In addition to chestnut honey, mad honey samples were obtained from local beekeepers. Following established procedures previously mentioned, honey samples were harvested from the Yığılca local honey bee and the Anatolian honey bee. There is no predominant pollen in Yığılca mad honey samples so the honey type is multifloral. The secondary pollen taxa were identified as Castanea sativa and important minor pollen group was represented predominantly by Rhododendron ponticum, then Mespilus germanica, Prunus laurocerasus, Barbarea vulgaris, Lysimachia verticillaris, and Erica arborea in the Yığılca mad honey. Veronica sp., Poaceae, Echium vulgare, Ranunculus repens, Saponaria glutinosa and Apiaceae were identified in the minor pollen group (Table 3).

Table 3. Melissopalynological analysis of mad honey samples of Yiğılca and Anatolian honey bee

\begin{tabular}{|c|c|c|}
\hline Botanical origin & Honey $2 \%$ (frequency)* & Honey 4 \% (frequency)* \\
\hline Castanea sativa & $31.5(\mathrm{SP})$ & $72(\mathrm{PP})$ \\
\hline Rhododendron ponticum & 11 (IMP) & 5 (IMP) \\
\hline Mespilus germanica & 8 (IMP) & - \\
\hline Prunus laurocerasus & 7.5 (IMP) & - \\
\hline Barbarea vulgaris & 7.5 (IMP) & - \\
\hline Lysimachia verticillaris & 5 (IMP) & 7.5 (IMP) \\
\hline Erica arborea & 4 (IMP) & - \\
\hline Veronica sp. & 3 (MP) & - \\
\hline Poaceae & 2 (MP) & - \\
\hline Echium vulgare & 2 (MP) & - \\
\hline Ranunculus repens & 1 (MP) & - \\
\hline Saponaria glutinosa & $0.5(\mathrm{MP})$ & - \\
\hline Apiaceae & 0.5 (MP) & - \\
\hline Leguminosae & - & 1 (MP) \\
\hline Circaeae lutetiana & - & 1 (MP) \\
\hline Lathyrus laxiflorus & - & $0.5(\mathrm{MP})$ \\
\hline Not identified & 16.5 & 13 \\
\hline
\end{tabular}

According to our analysis of the sampled mad honey of Anatolian honey bee, Castanea sativa forms the group of dominant pollen, and an important minor pollen group was represented by Rhododendron ponticum and Lysimachia verticillaris. Minor pollen group included Leguminosae, Circaeae lutetiana, and Lathyrus laxiflorus.

The Sorensen similarity coefficient (ISS), calculating among the honey samples of the Yrğılca and the Anatolian honey bees, was $38.09 \%$. 


\subsection{Physicochemical analysis}

According to the standards of the Turkish food codex communique on honey (Ministry of Food, Agriculture and Livestock, 2012) and additional European legislation (The Council of the European Union, 2002), the chestnut and mad honey samples of the Yığılca local honey bee were deemed acceptable. The moisture contents of the honey samples of the Anatolian honey bee, in both the chestnut honey and mad honey, were higher than the allowed limits of $20 \mathrm{~g} / 100 \mathrm{~g}$ (22.8 and 23.5, respectively). Other parameters were also deemed acceptable. The results obtained for the various physicochemical parameters are presented in Table 4.

HMF and diastase activity were the specific parameters used to determine honey heating. These parameters were found acceptable in both the chestnut honey and the mad honey samples of both the Anatolian honey bee and the Yiğllca local honey bee. Electrical conductivity and free acidity values for both chestnut honey and mad honey samples were also within the accepted limits. Honey $\mathrm{pH}$ is of importance during extraction and storage because it affects stability, texture, and shelf life of the honey. The $\mathrm{pH}$ levels of the mad honey samples were 3.84 and 4.00, respectively, from the Anatolian honey bee and the Yiğılca local honey bee. In the chestnut honey samples, the pH was 5.00 and 5.25 (from the Anatolian honey bee and Yığılca local honey bee, respectively). According to the difference $\delta^{13} \mathrm{C}$ value (limits $\geq-1$ ), both the mad honey and the chestnut honey samples were within the defined limits. C-4 sugar content indicated adulteration in honey, which should be under $7 \%$. All the studied honey samples were within these limits.

Table 4. Physicochemical parameters of honey samples

\begin{tabular}{|c|c|c|c|c|}
\hline & \multicolumn{2}{|c|}{ by Yığılca local honey bee } & \multicolumn{2}{|c|}{ by Anatolian honey bee } \\
\hline & Honey 1 & Honey 2 & Honey 3 & Honey 4 \\
\hline Diastase number & 13.9 & 10.9 & 17.9 & 8.3 \\
\hline HMF mg/kg & $\mathrm{UDL}^{*}$ & UDL* & UDL* & $\mathrm{UDL}^{*}$ \\
\hline Conductivity $\mathrm{mS} / \mathrm{cm}$ & 1.219 & 0.438 & 1.432 & 0.419 \\
\hline Moisture $\mathrm{g} / 100 \mathrm{~g}$ & 17.9 & 18.4 & 22.8 & 23.5 \\
\hline Free acidity $\mathrm{mmol} / \mathrm{kg}$ & 19 & 19 & 22 & 24 \\
\hline \multicolumn{5}{|l|}{ Sugar content g/100g ; } \\
\hline Fructose & 36.55 & 38.33 & 38.96 & 36.50 \\
\hline Glucose & 29.78 & 30.21 & 21.87 & 29.80 \\
\hline Sucrose & $\mathrm{UDL}^{*}$ & UDL* & 0.12 & $\mathrm{UDL}^{*}$ \\
\hline Maltose & $\mathrm{UDL}^{*}$ & UDL* & UDL* & $\mathrm{UDL}^{*}$ \\
\hline pH & 5.25 & 4.00 & 5.00 & 3.84 \\
\hline Proline mg/kg & 160 & 1173.33 & 1226.67 & 106.67 \\
\hline Difference $\delta^{13} C$ protein $-\delta^{13} C$ honey & -0.28 & -0.08 & -0.31 & -0.40 \\
\hline C4 sugar percentages & 1.69 & 0.43 & 1.87 & 2.31 \\
\hline
\end{tabular}

*UDL: Under the detection limit.

\section{Discussion and Conclusion}

Chestnut honey samples in this study identified monofloral honey, as expected. The sampled mad honey of the Yiğılca local honey bee was composed of multifloral honey. The presence of chestnut pollen is the highest across all honey samples collected. Chestnut flowers are one of the most preferred melliferous flowers for honey bees in Düzce province. Both types of honey bee prefer chestnut pollen within the research area studied. Kaya et al. (2005) analyzed 13 honey samples from different regions in Turkey. They showed that two honey samples from Bartın (Black Sea Region) contain Castanea sativa pollen as the dominant pollen and that one of them possesses Rhododendron pollen as its secondary pollen. Besides, another honey sample from Bolu (Black Sea Region) contains Rhododendron pollen as the dominant pollen and Erica pollen as the secondary pollen in their study.

In this study, mad honey samples from the Yığllca local honey bees and the Anatolian honey bees could not be identified as monofloral honeys with regards to Rhododendron spp., but they are 
known and labeled as a mad honey in the district in question. Lysimachia verticillaris pollens were identified in all mad honey samples, and it is a preferred plant for both types of honey bees. Plant diversity is higher among the honey of the Yığılca local honey bee than in the Anatolian honey bee's honey.

According to Sorensen similarity coefficient, pollen composition of honey samples produced by the Yığılca local honey bee and the Anatolian honey bee was $38.09 \%$ similar, while the melliferous flowers around the hives was $51.85 \%$ similar. Pollen diversity was also higher in the Yığılca local honey bee.

Mayda et al. (2018) investigated chestnut and Rhododendron honeys in Turkey. In their results, six mixed chestnuts and Rhododendron, two monofloral Rhododendron, and ten monofloral chestnuts honeys were identified. Kambur et al. (2015) analyzed ten honey samples from the Yığılca district. Three samples were identified as monofloral (Rhododenron ponticum and Castanea sativa) and the other remaining samples were identified as multifloral. Secondary pollen families were identified as Fabaceae, Fagaceae, Poaceae, Apiaceae, and Asteraceae in multifloral honeys.

Di Marco et al. (2017) studied different monofloral Italian honeys. In all Rhododendron honey, the presence of Rhododendron pollen frequency was measured at between $15 \%$ and $45 \%$. C. sativa pollen is dominant in chestnut honeys, and it was represented with a frequency of $>45 \%$. The pollen of the other taxa was poor. Lamiaceae species, Ailanthus altissima, Prunus, Tilia sp., and Rhododendron sp. were found in C. sativa honey from North Italy. Mediterranean elements such as Cistus sp., Eucalyptus sp., Citrus sp., and Olea sp. were present in C. sativa honey from Southern Italy.

According to the standards of the Turkish food codex communique on honey and additional European legislation, the chestnut honey and mad honey samples of the Yı̆̆1lca local honey bee were deemed acceptable. The moisture contents within the honey samples of the Anatolian honey bee, in both the chestnut honey and the mad honey, are higher than the allowed limits of $20 \mathrm{~g} / 100 \mathrm{~g} \mathrm{(22.8}$ and 23.5, respectively). As a result of our interviews with the local beekeepers, it was thought that the amount of moisture present in the honey samples of the Anatolian honey bee may possibly be caused by the rainy weather during the honey season. It can also be due to the early honey harvest. Other parameters were found acceptable. Kambur et al. (2015) analyzed 10 honey samples from Yığılca. Three of them were monofloral honey (Rhododenron ponticum and Castanea sativa were dominant) and others were multifloral honey. According to physicochemical results, $\mathrm{C} 4, \mathrm{C} 13(8.72 \%,-1.39)$ and free acidity (70 $\mathrm{meq} / \mathrm{kg}$ ) level of two multifloral honey samples were found slightly high. Other parameters were found acceptable in studied samples. Derebaş1 et al. (2014) studied physicochemical parameters (ash, moisture, $\mathrm{pH}$, acidity, diastase activity, HMF, electrical conductivity, invert sugar and sucrose) of 209 honey samples which were obtained from Black Sea Region. They found the mean values for these parameters as appropriate according to standards. On the other hand, $24 \%, 8 \%$ and $12 \%$ of the samples are not suitable for diastase activity, invert sugar and sucrose, respectively. Besides that, residue analysis was done. Although honey samples were suitable in terms of pesticide residues, $33 \%$ and $10 \%$ of them were not suitable for antibiotic and naphthalene residues, respectively.

In conclusion, the botanical composition of the honey samples which were produced by the Yığılca local honey bee and the Anatolian honey bee were analyzed. The diversity of the Yığılca local honey bee's samples was higher than the Anatolian honey bee's samples. This study facilitated the collection of information regarding melissopalynological analysis of honey samples of the Yiğılca local honey bee.

Chestnut honey samples of both honey bees were classified as monofloral honey due to the predominant pollen of Castanea sativa. The samples were labeled as mad honey from the Anatolian honey bee by local beekeepers, and it contained Castanea sativa pollen as the predominant pollen and Rhododendron ponticum and Lysimachia verticillaris pollens as important minor pollens as well. For this reason, it was classified as monofloral honey. The honey samples of the Yığılca local honey bee, which were labeled as mad honey by local beekeepers, was multifloral honey and contained Castanea sativa pollen as its secondary pollen and Rhododendron ponticum, Mespilus germanica, Prunus laurocerasus, Barbarea vulgaris, Lysimachia verticillaris, Erica arborea pollens as important minor pollens. 


\section{Acknowledgment}

We would like to thank local beekeepers who helped us for providing honey samples during our fieldwork. This work was supported by Tübitak 2209-A.

\section{References}

Adam, B. (1983). In search of best strains of honeybees. Northern Bee Books, West Yorkshire.

Akçakoca Municipality. (1999). Geographical structure. http://www.akcakoca.bel.tr/akcakoca/cografiyapi/ (Accessed: 02.11.2020).

Altay, V., Karahan, P., Karahan, F., \& Öztürk, M. (2018). Pollen analysis of honeys from Hatay/Turkey. Biodicon 11(3), 209-222.

Bozbeyoglu, N., Arslan, S., Guvensen, A., \& Mercan Dogan, N. (2019). Bacteriological, physicochemical, and melissopalynologic properties of some Turkish honeys. Akademik Glda, 17(2), 167-175.

Çakır, Y., Çobanoğlu, D. N., Dervişoğlu, G., Koçyiğit, S., Karahan, D., \& Yelkovan, S. (2020). Determination of antimicrobial activity, palynological characteristics and chemical composition of some honey samples from Turkey. Mellifera, 20(1), 41-60.

Cenet, M. (2019). Pollen analyses and antimicrobial properties of the natural honey from the east mediterranean part of Anatolia. Pakistan Journal of Zoology, 51(2), 541-548.

Davis, P. H. (Ed.) (1988). Flora of Turkey and the East Aegean Islands, vols. 1-9. Edinburgh University Press, Edinburgh.

Derebaş1, E., Bulut, G., Col, M., Güney, F., Yaşar, N., \& Ertürk, Ö. (2014). Physicochemical and residue analysis of honey from Black Sea region of Turkey. Fresenius Environmental Bulletin, 23(1), $10-17$.

Di Marco, G., Manfredini, A., Leonardi, D., Canuti, L., Impei, S., Gismondi, A., \& Canini, A. (2017). Geographical, botanical and chemical profile of monofloral Italian honeys as food quality guarantee and territory brand. Plant Biosystems, 151(3), 450-463.

Düzce Municipality. http://www.duzce.bel.tr/ (Accessed: 09.11.2020).

Ecem Bayram, N., Yüzer, M. O., \& Bayram, S. (2019). Melissopalynology analysis, physicochemical properties, multi-element content and antimicrobial activity of honey samples collected from Bayburt, Turkey. Uludag Bee Journal, 19(2), 161-176.

FAO. Live Animals, 2016. http://www.fao.org/faostat/en/\#data/QA (Accessed: 04.04.2020).

Gencay Celemli, O. (2020). Classification of Turkish honeys from Aydın-Karacasu-Dikmen village based on melissopalynological parameters. Communications Faculty of Sciences University of Ankara Series C Biology, 29(1), 105-118.

Gencay Celemli, O., Ozenirler, C., Ecem Bayram, N., Zare, G., \& Sorkun, K. (2018). Melissopalynological analysis for geographical marking of Kars honey. Kafkas Universitesi Veteriner Fakultesi Dergisi, 24(1), 53-59.

Gösterit, A., Kekeçoğlu, M., \& Çikili, Y. (2012). Comparison of some performance traits of Yigılca local honey bee with Caucasian and Anatolian crosses. Suleyman Demirel University Journal of the Faculty of Agriculture, 7(1), 107-114.

Gül, A., \& Pehlivan, T. (2018). Antioxidant activities of some monofloral honey types produced across Turkey. Saudi Journal of Biological Sciences, 25, 1056-1065.

Güner, A., Özhatay, N., Ekim, T., \& Başer, K. H. C. (Eds) (2000). Flora of Turkey and the East Aegean Islands, vol. 11. Edinburgh University Press, Edinburgh.

Gürbüz, S., Gençay Çelemli, Ö., Özenirler, Ç., Mayda, N., Özkök, A., \& Sorkun, K. (2019). Melissopalnological analysis of honey samples collected from Şırnak city. Uludag Bee Journal, 19(2), 126-135.

Gürbüz, S., Özenirler, Ç., Mayda, N., Gençay Çelemli, Ö., \& Özkök, A. (2019). Pollen spectrum of some honey samples produced in Siirt-Turkey. Hacettepe Journal of Biology and Chemistry, 47(3), 295-303.

Halbritter, H., Werber, M., Zetter, R., Frosch-Radivo, A., Buchner, R., \& Hesse, M. (2010). Illustrated handbook on pollen terminology. PalDat, Vienna. 
Hesse, M., Halbritter, H., Weber, M., Buchner, R., Frosch-Radivo, A., Ulrich, S., \& Zetter, R. (2009). Pollen terminology, An illustrated handbook. SpringerWienNewYork, Vienna.

Kambur, M., \& Kekeçoğlu, M. (2020). Is the natural honey bee biodiversity of Anatolia in the process of extinction? Yuzuncu Yil University Journal of Agricultural Science, 30(3), 593-600.

Kambur, M., Kekeçoğlu, M., \& Yıldız, İ. (2015). Assesment of the honey samples produced in Yığılca district of Düzce city by using chemical and palynological analysis. Uludag Bee Journal, 15(2), 67-79.

Kandemir, I., Kence, M., \& Kence, A. (2000). Genetic and morphometric variation in honeybee (Apis mellifera L.) populations of Turkey. Apidologie, 31(3), 343-356.

Kaya, Z., Binzet, R., \& Orcan, N. (2005). Pollen analyses of honeys from some regions in Turkey. Apiacta, 40, 10-15.

Kekecoğlu, M. (2010). Honey bee biodiversity in Western Black Sea and evidence for a new honey bee ecotype in Yı̆̆ılca provinces of Düzce city. Research Journal of Biological Sciences, 3(1), 7378.

Kekecoglu, M., \& Goc-Rasgele, P. (2013). Physico-chemical analyses of Turkish honey samples. Food Analysis, 24(1), 38-41.

Kekecoglu, M., \& Soysal, M. I. (2010). Genetic diversity of bee ecotypes in Turkey and evidence for geographical differences. Romanian Biotechnological Letters, 15(5), 5646-5653.

Kılıç, F., \& Bilgen, G. (2006). Enzyme polymorphism in honeybee (Apis mellifera L.) populations from Izmir province. Journal of Agriculture Faculty of Ege University, 43(1), 75-84.

Kızılpınar Temizer, İ., Güder, A., \& Türkmen, Z. (2019). Assessment of palynological characterization and total phenol-flavonoid content of some honeys from Ordu in Turkey. Erzincan University Journal of Science and Technology, 12(3), 1275-1282.

Louveaux, J., Maurizio, A., \& Vorwohl, G. (1978). Methods of melissopalynology. Bee World, 59(4), 139-157.

Mayda, N., Özkök, A., \& Sorkun, K. (2018). Some characteristic properties of chestnut and Rhododendron honeys in Turkey. Hacettepe Journal of Biology and Chemistry, 46(1), 135-145.

Ministry of Food, Agriculture and Livestock (2012). Turkish food codex communiqué on honey. Official Gazette. 28366.

Moraes, F. J., Garcia, R. C., Galhardo, D., Camargo, S. C., Pires, B. G., Pereira, D. J., \& de Sousa, P. H. A. A. (2019). Pollen analysis of honey samples produced in the counties of Santa Helena and Terra Roxa, western Region of Paraná, Southern Brazil. Sociobiology, 66(2), 327-338.

Özenirler, Ç., Mayda, N., Gençay Çelemli, Ö., Özkök, A., \& Sorkun, K. (2018). Dandelion honey: a new monofloral honey record for Turkey. Uludag Bee Journal, 18(2), 87-93.

Ozkok, A., Ozenırler, C., Canlı, D., Mayda, N., \& Sorkun, K. (2018). Monofloral features of Turkish honeys according to melissopalynologic, total phenolic and total flavonoid content. Gazi University Journal of Science, 31(3), 713-723.

Özler, H. (2018). Pollen analysis of the honey from south Anatolia. Uludag Bee Journal, 18(2), 73-86.

Ruttner, F. (1988). Biogeography and taxonomy of honeybees. Springer-V, Berlin Heidelberg.

Silici, S., \& Gökceoglu, M. (2007). Pollen analysis of honeys from Mediterranean region of Anatolia. Grana, 46(1), 57-64.

Sorkun, K. (2008). Turkey's nectar plants, pollen and honey. Palme, Ankara.

Sorkun, K., Gençay Çelemli, Ö., Özenirler, Ç., Bayram, N. E., \& Güzel, F. (2014). Palynological investigation of honey produced in Ardahan-Turkey. Bee World, 91(3), 80-83.

The Council of the European Union. (2002). Council Directive 2001/110/EC of 20 December 2001 relating to honey. Official Journal of the European Communities.

TUIK. Livestock statistic database. (2019). https://biruni.tuik.gov.tr/ hayvancilikapp/hayvancilik.zul (Accessed: 04.042020).

Wodehouse, R. P. (1935). Pollen Grains. Mc Grew Hill, New York.

Yigilca Department of Forestry. https://boluobm.ogm.gov.tr/YigilcaOIM/ Sayfalar/default.aspx (Accessed: 09.11.2019).

Y1gılca Municipality. http://www.yigilca.bel.tr/ (Accessed: 10.03.2020). 